\title{
Regulating South Africa's retirement funds: The case for clearer objectives
}

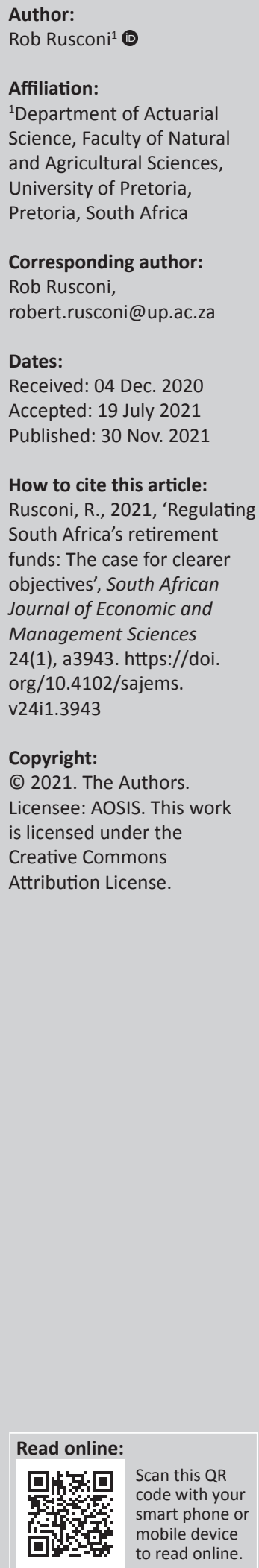

The rationale for the regulation of participants in financial markets, like retirement funds, is sound. It would be strengthened, however, by a clear statement of the objectives of such regulation. In this article the position is taken that the objectives underpinning the regulation of South African privately-managed retirement funds should be enhanced. It presents this argument with reference to international principles concerning systems of old-age provision, and to the examples of regulations in other jurisdictions. It recommends a set of practical regulatory objectives in the pursuit of efficiency, sustainability, coverage, adequacy and security of provision for old age.

Keywords: retirement funds; financial markets; regulatory objectives; social protection; government policy.

\section{Introduction}

While the rationale for the regulation of financial markets is well-established (Llewellyn 1999; NTSA 2011a; Organisation for Economic Cooperation and Development Publishing, or OECD 2010), the effectiveness of these regulations could be improved, were regulators to publish the objectives of such regulation and monitor the extent to which the objectives are being achieved (Baldwin \& Black 2016; Black 2012). Explicitly stated objectives enhance accountability (Sarkar 2009), provide the means to track progress (Knot 2014) and enhance the rationale for regulatory intervention (OECD 2010). These motives are all particularly pertinent to South Africa. In this paper it is argued that more could be done by South Africa's regulator of retirement funds, the Financial Sector Conduct Authority (FSCA), to make clear its objectives.

In the next section, the rationale for the regulation of financial markets and participants such as retirement funds is reviewed. In the following section, the objectives stated by the regulators of other retirement-saving markets are summarised. Thereafter, South Africa's market for retirement saving is described and consideration is given to the extent to which regulatory objectives are clearly stated. A number of recommendations follow and the paper closes with consideration of possibilities for further research.

\section{Rationale for regulating financial markets}

Financial markets play an enormously important part in supporting the interactions of participants in economies of all sizes, from remote communities to the global village (OECD 2010). The interactions between these participants are numerous, widespread, diverse and increasingly complex (Erskine 2014).

As critical as they are to the global economy and all of its component parts, financial markets exhibit remarkable fragility. The operations of these markets are subject to failures of various kinds, such as information inequality (Healy \& Palepu 2001), market-power imbalances (Khwaja \& Mian 2011), principal-agent conflict (Laffont \& Martimort 2002) and contagion (Brunnermeier et al. 2009), with sometimes catastrophic consequences, such as the global financial crisis of 2008-2009. This propensity for distortions in financial markets and the potentially damaging impacts of widespread failure are typically utilised as the basis for the regulation of these markets (OECD 2010). The rationale for regulating financial markets thus rests on the combination of their importance to society and their considerable complexity. Regulation itself, however, may contribute to the potential for market failure (Bisias et al. 2012); while regulation aims to mitigate the risks of market failure, the activities of regulators impact the operation of markets and can exacerbate exactly the risk that it seeks to address, by altering competitive pricing dynamics, for example. 
Retirement funds, privately or publicly managed, form a critical part of the system of old-age provision, itself an element of any country's system of social protection. They both participate in and utilise financial markets to an enormous extent, as very large investors of assets. Despite falling in value over the course of the year, global assets in retirement funds at the end of 2018 amounted to well over USD 40000 billion in value (OECD 2019). The existence of these funds generates income for a substantial community of providers, operating both within and alongside the financial markets. Their allocation of assets to available opportunities can make a substantial difference to the nature of the economies within which they are located.

Retirement funds play a substantial role in many economies (Holzmann 1999; Holzmann et al. 2005; James 1995; Willmore 2000; World Bank 1994). They provide a vital contribution to government policy on social protection. They typically attract a considerable share of government expenditure (in this case, income foregone) in the form of tax incentives of various kinds. Retirement fund membership often includes a high proportion of the working and elderly residents of a country; though, across countries, levels of coverage vary significantly. They play a significant role in labour dynamics and employment practices, representing deferred income to workers, typically more effectively and efficiently provided than would be possible by the workers on their own.

\section{Supervisory objectives in other jurisdictions}

In the discussion that follows, the publicly-stated objectives of the respective regulatory authorities overseeing retirement funds in five countries are presented. Seven countries were assessed, three advanced retirement funding markets in developed countries (Australia, the Netherlands and the United Kingdom), two emerging Latin American systems (Chile and Mexico) and two African markets (Kenya and Nigeria). These countries were selected with their diversity in mind and in the expectation of regulatory objectives. No such objectives were found for the Netherlands and Mexico.

Retirement funds in Australia are overseen by the Australian Prudential Regulation Authority (APRA), which expresses its regulatory goals in a publication dedicated to the purpose (APRA 2019a). The Australian Prudential Regulation Authority states its key objectives as the financial security of the entities under its remit and the stability of the financial system as a whole. It recognises four second-tier considerations: efficiency, competition, contestability and competitive neutrality, which typically reinforce each other but sometimes come into conflict with one another (APRA 2019a). The Australian Prudential Regulation Authority expands on its objectives by preparing and releasing, every year, a corporate plan that extends four years into the future (APRA 2019b). This identifies focal areas for the near future and establishes a number of performance measures through which it seeks to achieve its objectives. Each year, it reports progress in meeting its strategic objectives within the constraints of these measures (APRA 2019c).

The Pensions Regulator (TPR) is responsible for overseeing privately-managed retirement arrangements in the United Kingdom (TPR 2019b). The Pensions Regulator works under six statutory objectives, which it expands into four outcomes and eight outcome indicators. Every year it reviews its plans, resolving six corporate priorities and 18 key performance indicators (TPR 2019a), three indicators to each priority. The annual report of the TPR sets out a thorough assessment of progress against its performance indicators (TPR 2019b). The Pensions Regulator prominently discloses five areas of responsibility (thepensionsregulator.gov.uk, accessed 15 June 2020) and backs this up with the six priorities for the period 2019-2022, which it describes in more detail in its corporate plan (TPR 2019a).

Chile runs an individual retirement account system, to which workers must make contributions. The pension's superintendent (La Superintendencia de Pensiones, SP) has been responsible for overseeing the (relatively few) entities registered to manage pension savings under the individual account system since 2008, when it replaced the original superintendent (spensiones.cl, accessed 15 June 2020). The SP describes its mission in terms of four strategic objectives. It publishes a formal description of priorities to its line ministry (SPC 2019a). It also provides a summary of strategic intent for the period 2019-2022. In addition, the SP publishes annual summaries, written for broader public consumption (SPC 2019b).

All funded arrangements in Kenya (IOPS 2012) are regulated by the Retirement Benefits Authority (RBA). The RBA describes its mandate in broad terms and discloses clear objectives in its strategic plan for the period 2019-2024 (RBA 2019). It sets out three strategic themes and translates these into a set of strategic objectives. The RBA strategic plan also includes: (1) descriptions of the stakeholders of the RBA, (2) the key risks that it faces and its appetite for each of these risks, and (3) the monitoring and evaluation framework of the authority. Yet to be seen is how transparently it reports its progress against these goals.

Nigeria's individual account system is overseen by a dedicated regulator, the National Pension Commission (Pencom). The Pencom statement of mission focuses on the benefits of sound regulation to workers covered under the system, but the vision states the aspiration, by 2020, for 20 million contributors and a measurable impact on the Nigerian economy (pencom.gov.ng, accessed 17 June 2020). It builds on this through its statement of five objectives, presenting a mix of high-level aspiration concerning the size of the scheme and a determination to address pressing operational challenges. The annual report (NPCN 2018) does not reiterate these objectives or provide any information on progress against them.

While, a systematic analysis of the similarities and differences between the objectives in other jurisdictions was 
not utilised, a number of observations follow from this brief study of the approaches taken by the authorities in these countries. Firstly, different approaches are evident, meticulous in the United Kingdom and Australia, ambitious and wide-ranging in Kenya and Nigeria, clear but somewhat understated in Chile. Secondly, having a dedicated pension supervisor appears to be helpful to the definition of goals, because such a person represents the entire ambition of that organisation. Thirdly, though an improved knowledge of the respective political economies would assist in the understanding, policy support appears to matter. Finally, in practice, few hindrances appear to exist to any supervisory authority, with the support of policymakers and within the constraints of its legal mandate, from adopting a strong and transparent set of objectives supported by a measurable set of outcomes.

\section{The South African retirement fund market}

The retirement fund industry in this country is large. The most recent report of the Financial Services Board (FSB 2018) cites total assets across all fund types as R4262 bn. This amounts to $89.3 \%$ of the end-2017 value of the Gross Domestic Product of R4772 bn (South African Reserve Bank, SARB, resbank.co.za, viewed 08 June 2020). An OECD (2019) assessment puts South African privately-managed retirement assets in 2016 among developing countries at second in dollar terms, and first as a percentage of GDP.

Membership of these funds is more difficult to determine with certainty. The FSB (2018) reports total membership of all funds as 16.9 million at the end of 2017, against an end2017 labour force of 22.1 million and total employment of 16.2 million (statssa.gov.za, viewed 08 June 2020). In fact, only 11.2 million of the members are reported by the FSB as contributing to their retirement funds. Some 950000 are pensioner members. Approximately 4.5 million, some of them potentially also pensioners, are eligible for unclaimed benefits. Furthermore, it is reasonable to assume significant double-counting of these 11.2 million contributing members.

Until recently, South Africa regulated its banks from the SARB and all other financial-market participants through the non-bank regulator, the FSB. Following the patterns established by a number of other countries, Australia and New Zealand for example, regulation of all financialmarket entities has been split between two specialist organisations. Prudential regulation now falls to the newly established Prudential Authority (PA), which is located at the SARB. Market-conduct regulation is the responsibility of the FSCA, based at the offices of the defunct FSB. Retirement funds fall into a special category of entities whose prudential oversight is the responsibility of the FSCA, but the PA has indicated that it is expected to take responsibility for the prudential oversight of retirement funds from 01 April 2021 (PASA 2020).

\section{Policy context}

While current assets in retirement funds are high, household saving levels are not. Gross nominal household saving amounted to $1.3 \%$ of GDP throughout 2019 (seasonally adjusted, SARB 2020). This is marginally higher than over the previous decade, but low by international standards. The OECD cites South Africa's household saving rate at $0.26 \%$ of household disposable income in 2017, the first year since 2005 with a positive value, in position 27 out of 34 jurisdictions included, mostly industrialised countries (data.oecd.org, viewed 09 June 2020).

South Africa's privately managed retirement system is large by international standards, because, rare among developed or upper-middle-income developing countries, it offers no national-level retirement savings vehicle, publicly or privately run, to which contributions are mandatory. This is inconsistent with both the World Bank multi-pillar model, which emphasises a shared approach to old-age provision across a number of variables, and the corresponding framework of the International Labour Organisation that focuses on the role of the state as primary provider of social protection (ILO 2017; World Bank 1994). Retirement saving, supported by tax incentives, is thus directed to these privately managed vehicles, increasing the importance of sound regulatory objectives over such entities. While South Africa does provide near-universal old-age income to a large proportion of its elderly citizens, this is not designed to meet the needs of its low-income workers, many of whom are effectively excluded from the system of retirement saving.

South Africa's unusual approach to social protection for the elderly has been acknowledged and discussed by policymakers for some time (Committee of Inquiry 2002; DSD 2006; NPCSA 2012; NTSA 2004, 2007, 2015). It is widely agreed that the system of private provision for retirement in South Africa suffers major flaws and does not, by and large, achieve its primary objective of providing effectively for the retirement needs of workers. Preserving retirement savings is not compulsory, notwithstanding broad agreement on the principle and repeated efforts by policymakers to render it so. The outflow from retirement funds significantly exceeds the corresponding inflow. The membership of retirement funds appears to be broadly healthy, but it is, in fact, very poor in some industry sectors and income bands (NTSA 2013). The durability of accumulated saving after retirement is also being brought into question, given the investment risks carried by members in their defined contribution arrangements and evidence of high rates of drawdown in retirement in preference to purchasing an annuity guaranteed for life (NTSA 2012).

The primary concerns of those representing the working poor and the unemployed are that the system does not work effectively to mitigate the retirement risks of those with low income or interrupted work, and that the redistribution to the poor, implicit in the system of social grants, is inadequate. Policymakers have, until now, appeared not to be able to 
agree on priorities for social protection and the potential path of reform. It is not clear where this leaves South Africa's retirement funds, or the regulator overseeing them.

\section{The challenges of retirement fund regulation}

If they are to be effective, the objectives that the regulatory authority establishes must recognise the flaws in the market under consideration and the steps that may be taken to mitigate these flaws. Before turning to examining the manner in which the FSCA establishes its priorities, consideration is given to the challenges of regulating retirement funds. These entities are marked by complexity of various forms. This complexity makes it more difficult to identify and mitigate potential market failures through regulation.

The financial management of defined benefit funds, which provide guarantees of exceptional duration, calls for careful attention, skill and experience (Clark \& Monk 2006a, 2006b; Cowling et al. 2019; Franzen 2010). Less obvious, but perhaps more dangerous, is the risk borne by members of defined contribution funds and the challenge that these members are largely not able to manage this risk (Randle \& Rudolph 2014; Stewart \& Yermo 2008). These funds now dominate provision by private-sector workers in South Africa. Operations are complex. Optimising the investment of assets is not straightforward. Perhaps the most intractable problem to the regulatory authority, however, is the complexity inherent to the system of governance and the deep dependence of retirement-fund members on the effectiveness of such governance in practice.

In South Africa, as in many countries, the legal framework establishing oversight of retirement funds concentrates substantial responsibility in the hands of a few. The exercise of this responsibility is inadequately scrutinised by the ultimate stakeholders of these funds, the members and beneficiaries, who generally do not have the skill to exercise such scrutiny. The resulting outcomes are widely regarded as inadequate (DSD 2006; NPCSA 2012; NTSA 2004, 2007, 2013).

South Africa, in addition, employs a limited approach to enforcing minimum standards of expertise and experience of these few. The management board of a retirement fund represents the interests of the fund and all of its stakeholders. Quite how it balances the respective interest of the fund and its members has been the subject of vigorous debate.

Consider the complex dynamics of the principal-agent relationship. The trustees play the role of agent for the principals, ultimately the members and beneficiaries. Typically, though, the trustees do not have the expertise to invest the assets of the fund themselves. Bearing in mind the nature and extent of their responsibilities, they engage asset managers and advisors of various types to facilitate this. In this engagement, however, they act as principals over a range of agents, many of whom are experts in their fields and have considerable information advantages over their clients. Even simple interactions between principals and agents introduce the possibility of far-reaching conflicts of interest and distorted incentives. With the stakes as high as they are in retirement funds, the regulatory task to minimise the potential for market distortions and their consequences is formidable.

A special case in point is the set of multi-employer funds, typically referred to as umbrella funds in South Africa. They appear to be the preferred vehicle of the regulator for addressing operational inefficiency by consolidating smaller funds. These entities present a pertinent challenge in the management of conflicts of interest, however. Umbrella funds are, in nearly all cases, established and controlled by a for-profit entity, which seeks a return on its investment. This fundamentally distorts the operation of a fund that, in law at least, is supposed to operate in the interests of its members and beneficiaries. Efforts to address this, forcing options to allocate assets elsewhere, for example, or ensuring that at least half of the trustees are independent, cannot overturn the underlying commercial conflict.

Finally, it is not clear how retirement funds contribute to policy objectives. Consider the five criteria commonly stated in international circles for a retirement system. These are: efficiency, sustainability, coverage, adequacy and security (Price, Ashcroft \& Hafeman 2016). The extent to which privately managed retirement funds are able to contribute to all of these goals, is questionable. These funds have no influence on the extent to which coverage objectives might be met, for example. They are legally established as not-for-profit entities that do not actively seek new members. Defined contribution arrangements cannot deliver on the goal of adequacy unless the contributions paid by employers and members are adequate. These constraints typically leave the regulator focusing on operational efficiency and integrity and on the role of governance in supporting the security of member claims on the fund (Randle \& Rudolph 2014). This is only a small part of delivering on the promise of retirement funding:

These issues provide a taste of the intractable challenges facing the regulator of retirement funds in South Africa. The funds have enormous investing potential and substantial responsibility to millions of members. They are typically overseen by trustees, often with inadequate skill who, in delicate positions, have to manage as best they can in the face of the substantial power and interests of information-rich providers of service. The power imbalances and conflicts of interest that characterise this market appear to introduce intractable market distortions. Under these circumstances, clearly stated regulatory objectives are surely a minimum requirement.

\section{South African supervisory objectives}

In the discussion that follows, the stated objectives of a number of South Africa's financial-market regulators are considered, ending with the goals of the retirement fund unit of the FSCA. 
This assessment starts by considering whether, in its responsibility to regulate other parts of the financial markets, South Africa's policymakers and regulators generally have taken care to express their regulatory objectives and determine progress against these objectives. At legislative level, objectives are consistently defined with clarity. The objectives of the PA, for example, that are expressed in the Financial Regulation Act, 2017, are consistent with the highlevel goals set out in the paper that established the way forward for the financial sector (NTSA 2011b). The legislation continues with a description of the functions required by the PA to meet its objectives and of the power to put in place further functions in order to achieve the objective established for it. The market-conduct regulator is similarly authorised to act in pursuit of its objectives.

Law sets out high-level objectives. These need to be translated by regulators into a more tangible set of outputs if they are to be useful. The PA has expressed its objectives, the five priorities that it intends to focus on in pursuit of these objectives and, for each of these, the outcomes that it regards as defining adequate progress towards achieving such priorities (PASA 2018). The first annual report of the PA (PASA 2019) indicates its progress to date, albeit not directly against the goals and outcomes set out in its strategy.

Under the terms of the Financial Sector Regulation Act (2017), the FSCA is required (Section 70) to develop and adopt a regulatory strategy, which must set the regulatory and supervisory priorities for the next three years and describe the principles under which it is to perform its functions. It must also review its strategy no less frequently than annually. The FSCA strategy paper (2018) sets out priorities for the FSCA as a whole, among them 'a robust regulatory framework that provides fair customer treatment, informed financial customers [and] strengthening the efficiency and integrity of our financial markets' (FSCA 2018:5). It does not define objectives specific to its mandate to oversee retirement funds.

Under the draft terms of the Conduct of Financial Institutions Bill (2018), which was issued in December 2018 and by June 2020 had passed through the first draft of consultation, the FSCA is furthermore mandated to promote the objectives of the law, which are set out in the Bill itself. It also makes reference to the objectives of the FSCA, as defined in the Financial Sector Regulation Act (see paragraph 5.2) and sets high standards for the FSCA to assess the success with which any provisions that it makes under the Bill, achieve its stated objectives. The FSCA, in other words, has the power to establish its regulatory objectives and the mandate to report on the success with which it achieves them.

More widely, South Africa's financial-sector policymakers have a good track record of explaining the reasons for proposed reforms to the regulatory framework. Among regulators, the SARB is particularly transparent in its statement of objectives and the extent to which it is making progress towards these goals (SARB 2017).
A look back at the practices of the FSB are helpful. The supervisory authority had a sound history of stating its goals and expanding its mission and vision into a number of parts. It expressed its mission:

To promote fair treatment of consumers of financial services and products, financial soundness of financial institutions, systemic stability of financial services industries, integrity of financial markets and institutions and consumer financial education. (FSB 2017:13)

The FSB also defined objectives and performance indicators. It stated progress against these indicators, in broad terms. In its last few annual reports (FSB 2017, for example), it described progress against a number of performance indicators.

Retirement funds are represented in a dedicated part of the FSB annual reports. That section includes descriptions of the responsibilities of key departments within the retirementfunds unit, a discussion of significant industry-related issues and a range of statistics regarding the retirement industry (FSB 2017). Objectives are not included, but the mission of the retirement fund unit is set out as follows:

To promote a safe and stable environment for members of retirement funds so that obligations of all stakeholders are met when due through our commitment, professionalism and teamwork. (FSB 2017:32)

The most recent available report covering retirement funds at the time of drafting appears to be the final report of Registrar of Pension Funds (FSB 2018), issued in December 2018 and covering the calendar year 2017. This paper describes the activities of the unit and extensive statistics on retirement funds, but does not report on progress against regulatory objectives. The FSCA, since its inception, does not appear to have published a report covering retirement funds.

To date, in conclusion, the FSCA has not formulated a set of objectives for retirement fund regulation in significant depth or breadth. While the criteria governing the success of a retirement system may be described as efficiency, sustainability, coverage, adequacy and security, the retirement funds unit at the FSCA has focused its objectives on safety and stability for the members of retirement funds.

In mitigation, it may be suggested that its objectives include elements of efficiency and adequacy. Evidence for the first exists in the market-conduct framework of which it forms a part, in statements regarding the need for industry consolidation and in its concern over the communication to members of projected retirement benefits. Regarding the second, the release of draft rules covering the calculation underpinning the description of projected retirement benefits (FSCA 2020) is an example of the customer-centric approach of the FSCA.

South Africa's retirement funds regulator operates in the context of considerable policy uncertainty. This paper includes a number of references to the start-stop nature of the development of this policy over many years. Opaque policy 
regarding the role of retirement funds may make it more difficult for the regulator to set its objectives. Recently, however, with the powers granted to the FSCA to develop regulation (primarily by the Financial Sector Regulation Act 2017), the status of the overseeing entity was effectively raised from the position of supervisor to regulator. This gives the FSCA the authority to amend its regulatory strategy at any time, subject to appropriate consultation.

\section{Recommendations}

In the discussion that follows the options available to the FSCA to clarify its regulatory objectives concerning retirement funds are considered. This calls for a systematic approach to the retirement funding system, the risks of market failure and actions that may be taken by regulators to overcome these risks. The approach that follows, considers - for each of the primary goals of a framework for old age provision, efficiency, sustainability, coverage, adequacy and security - what role the retirement fund unit at the FSCA might play to develop and meet its regulatory objectives. Considering regulatory priorities along the lines of these primary goals, provides a sound foundation and a better chance of completeness than an alternative method.

\section{Efficiency}

Defined contribution retirement funds are effectively owned by their members. The trustees of these funds should be doing everything they can to ensure that they utilise member resources as effectively as possible, taking into account the costs and corresponding benefits of alternative actions. The market-conduct framework of the FSCA facilitates oversight of the extent to which funds manage their expenses in the pursuit of the most appropriate outcome for their members.

A number of approaches might be used by the FSCA to track fund expenses and influence trustees to operate with appropriate efficiency. Setting limits is not recommended as it runs the risk of distorting the operation of markets (BarGill 2015; Loube 1995), but requiring funds to report expenditure electronically and gathering comparative information across the industry, could lead to the development of benchmarks that might influence behaviour appropriately.

Perhaps more important, however, and more closely in line with the market-conduct philosophy of the FSCA, is that retirement funds demonstrate their focus on efficiency through their commitment to sound and effective governance. Boards of trustees themselves ought to acknowledge the impacts that their decisions have on the welfare of their members and make every effort to manage fund expenditure accordingly. Requiring the demonstrable implementation of effective governance and risk management by retirement funds would assist in building this responsibility.

Effective governance helps to overcome the potential for the pursuit of low costs at the expense of effective delivery.
Efficiency can only be gauged in terms of the effectiveness with which outcomes are delivered, which must take both costs and benefits into account. Regulatory objectives should be expressed in such terms.

\section{Sustainability}

Issues of sustainability appear to fall outside the brief of the retirement funds regulator. Sustainability is concerned with whether the value of contributions payable is sufficient, in the very long run, for the benefits provided. Old-age funding systems that are not sustainable are typically those that promise benefits without pre-funding and suffer the impacts of changes to the balance of contributors and beneficiaries (World Bank 1994). Defined contribution arrangements do not suffer from this problem, but if contributions are insufficient or members withdraw savings prior to retirement, then the sustainability of the system is without question inadequate as well. South Africa surely suffers this problem.

Much can still be done, at the level of the retirement fund, to improve sustainability. This should be reflected in regulatory objectives. Good governance, along with disciplined recordkeeping, financial management and regular actuarial reviews all contribute to the financial viability of a retirement fund and ultimately to the sustainability of the system as a whole by ensuring that the risks that members bear are managed as effectively as possible. A strong focus by the regulator on these disciplines, ultimately on the effectiveness with which members are supported in their risk-management challenge, would represent a sound contribution to sustainability at system level.

\section{Coverage}

Coverage also seems to fall outside the remit of the regulator, which does not have the power to require employers to make available to their workers a retirement fund or an efficient alternative individual arrangement.

The FSCA accepts its responsibility, however, to deliver financial education to South Africans. Highlighting the importance of saving for retirement should form part of this, not just in the environment of the workshop but through efforts to grow public awareness. Furthermore, contributing to efforts to identify more accurately how many South Africans are preparing financially for old age and how effectively they are doing so, would also be helpful. Finally, the FSCA has a significant role to play in contributing actively to the development of sound government policy regarding provision for old age. All of these might be reflected in its objectives.

\section{Adequacy}

South Africa faces enormous challenges regarding the adequacy of provision for old age. This is particularly acute among low-income workers who do not have access to a 
retirement fund and workers at all income levels who choose not to preserve their accumulated retirement saving when they leave employment, or switch from one job to another. The FSCA has access to the data needed to bring these concerns to light. Gathering sound information and reporting it through appropriate channels would contribute meaningfully to the development of sound policy.

Adequacy is also of critical importance at the level of the fund. Defined benefit funds typically provide for income in old age at a relatively generous rate, though they should take care to explain to members both the nature of this promise and the consequences of leaving the arrangement prior to retirement. For members of defined contribution funds, the situation is a great deal more difficult. These members bear the risk that, at retirement, they have not accumulated sufficient assets in their fund, along with other arrangements that they have made. They also take investment risk in the fund, a risk that these members typically do not have the skills to manage. A number of retirement funds undertake good work to communicate to their members the importance of planning ahead for old age by projecting to the date of retirement the income expected from savings accumulated to date, along with future contributions and investment returns. Under the responsibilities imposed on these funds by the marketconduct framework, the standards covering communication to members of the risks to which they are exposed, and the means for mitigating these risks, should be high.

The FSCA could assist in this process of communication, perhaps by issuing regular information leaflets using a variety of media that are designed for consumption by fund members. Under its market-conduct mandate, furthermore, the FSCA could establish minimum standards of communication to members by trustees. Overall, however, it is not clear that sufficient work is undertaken to test the effectiveness of communication to members. Communication that is either not understood or is not converted into appropriate action is wasted. The FSCA should frame regulatory objectives with this in mind.

\section{Security}

The security of retirement savings is the goal that lends itself most closely to the current regulatory model. It would be helpful as a start for the FSCA to explain what it means by 'safe and stable' and to identify the actions that it takes to achieve these ends.

Since the objectives underpinning regulation typically identify potential market failures and the steps required to address these, the FSCA could take this approach to defining its role as part of the ongoing process of establishing its regulatory mandate, taking into account the approaches utilised elsewhere. As a result, it might require trustees to adopt and follow strategic plans, consider issues of market competition, identify ways to improve management or aim to ensure that retirement funds overcome tendencies to view investment performance through a conservative short-term lens to the potential detriment of long-term success.
Under the powers now available to the FSCA to ensure an effective framework of market-conduct regulation, the regulator is well able to require all retirement funds to meet minimum requirements of governance and risk management and to demonstrate that they do so in the interests of all members. This could be supported by minimum standards of disclosure to members and a summarised version of this disclosure for public consumption, facilitating comparison across funds.

It is not clear how commercially established multi-employer arrangements would be able to demonstrate a best-practice approach to governance that is sufficiently strong to overcome the natural bias resulting from the commercial relationship of the fund with one financial service provider. One possibility for consideration by the regulator is to recognise that, by virtue of the inseparable relationship between the not-for-profit fund and the commercial entity that established it, additional regulatory requirements may need to be placed on these entities. These may help to address the limits to investment choice, the potential for compromises to the effectiveness of governance and the distortions to competitive dynamics between these entities and their stand-alone counterparts. While price controls are particularly dangerous to the effective operations of markets and are not recommended, an alternative might be minimum levels of public transparency of these entities concerning the fees that they charge and the range of services that they offer. Finally, it is difficult for groups of members to leave multiemployer arrangements, again impacting competitive dynamics. Minimum standards in this regard may be helpful. Lessons might be learned from the FSCA's Latin American counterparts, which utilise intense and intrusive approaches to manage the regulation of the few powerful commercial entities under their jurisdiction.

\section{Concluding comments}

The FSCA has been established with a strong mandate and supporting powers, and with few limitations on its scope, to exercise a lasting effect on the market:

A strong market conduct policy framework should support the delivery of desired policy outcomes in the financial sector, enable the monitoring of the extent to which those outcomes are being achieved, ensure preventative action is taken to mitigate the risk of poor outcomes, and ensure remedial action is taken when poor outcomes are in fact produced. (NTSA n.d.:11)

It is precisely the development of those outcomes that this paper encourages. The trustees of a retirement fund take enormous ethical and technical responsibility for the wellbeing of their members. They should be required to demonstrate how they meet minimum standards of governance, disclosure and risk management, failing which firm action should be taken by the regulator to improve these standards. Improving the seriousness with which retirement funds meet the needs of their members would go a long way to meeting the fundamental purpose of the FSCA and to clarifying the contribution of these funds to the social protection framework of the country. 


\section{Further research}

Research is critical in support of FSCA goals to improve the effectiveness of market operation to the advantage of the ultimate beneficiaries of these markets. A wide range of research has been carried out, internationally and locally, into the dynamics of choice faced by the members of retirement funds.

Consideration of the five policy objectives for old-age provision suggests a number of possibilities for further research in South Africa. Coverage and adequacy of retirement savings represent burning ships that need urgent attention. Not enough is understood about the quality of retirement fund coverage in South Africa and the split between those, with the benefit of tax incentives, who are saving for an income in retirement and those, members of provident funds, most likely on lower incomes, who will receive a lump sum and may well then draw an old-age grant. Little is also known about the nature of old-age income security, given the poor rates at which retirement proceeds are converted into lifetime annuities. Furthermore, the extent to which accumulated saving is preserved until retirement is not well understood, though it appears to be low. All of these provide an excellent reason for systematic information gathering and analysis, in all likelihood combining a number of sources. The FSCA itself may be in a strong position to coordinate this activity.

Efficiency considerations should also be high on the FSCA agenda, given its focus on sound market conduct. Analysis of the overall expenditure of retirement funds, on a year-by-year basis, suitably normalised to allow for asset and membership differences, should give to external commentators and to the funds themselves (not to mention their members) an opportunity to assess differences in the efficiency of these vehicles. The FSCA probably has better access to information than most and could carry out and publish this analysis itself. Industry bodies should have an interest in promoting transparency of this nature. In the interests of industry transparency, multi-employer funds and entities designed for individual take-up should also be publishing appropriately calculated and soundly balanced assessments of efficiency, supported by the Association for Savings and Investment South Africa. If they are not, the FSCA has a role to play in encouraging or mandating such publication.

Perhaps the most challenging area for scrutiny is that of the security of retirement saving. High-quality, detailed, reliable data is a necessary condition for effective research, but it is not sufficient. Market failure presents itself in a number of ways. Many of these channels of market distortion adversely impact member security because they affect the extent to which customers are able to act fairly in their own interest. It is not sufficient, for example, to note that administrative services or risk benefits are priced competitively, but not asset management, as appears anecdotally to be the case, if this is not supported by a careful understanding of why this may be the case and what might be done to address it.
High-quality research would be useful in a number of further areas, for example:

- the decisions that members of defined contribution funds take regarding the allocation of accounts to asset classes, both before and after retirement;

- the effectiveness of communication to members in terms of improved understanding and appropriate conversion of thoughts into action;

- the potential for goals-based arrangements and other methods from the disciplines of behavioural finance to improve retirement outcomes;

- the quality of governance and risk management at retirement funds, and the consequences of this quality on the performance of the funds and outcomes for members;

- the impacts, positive and negative, of the constrained models of governance that characterise funds that fall exclusively under the operational oversight of a commercial entity, multi-employer funds and those aimed at individuals;

- the impacts on the overall outcome for members of pricing investment management services as a percentage of assets under management rather than on an alternative basis such as a fee for service;

- the potential for inappropriate incentives to asset managers arising from performance-based investment fees; and

- the costs and benefits of directing resources to the management of operational risk in retirement funds.

The FSCA is surely the party most directly interested in an effectively operating retirement-funding market. It probably also has the best access to fund-level information. It should play a critical role in coordinating research into the market and its participants.

\section{Concluding comments}

Like many retirement funding markets, South Africa's ecosystem for private-sector old-age provision is large, complex and very important to a wide range of players. It is also characterised by deep challenges, particularly with regard to the alignment of incentives between principals and their agents. This ecosystem requires sound, effective oversight. The FSCA has been granted the power to exercise this oversight. To do so effectively, however, it needs to establish a set of regulatory objectives that are clearly stated and are translated into measurable outcomes. Progress against these outcomes should be reported upon regularly. In the context of opaque government policy regarding the role that privately managed retirement funds are to play in the social protection framework, this is difficult. It is, nevertheless, critical.

\section{Acknowledgements}

The research reported in this article is intended to contribute to completion of a PhD degree at the University of Pretoria. Some of the work was carried out as part of an MSc thesis 
completed in 2019 at the University of Pretoria. I am grateful for the guidance provided by supervisors Prof Conrad Beyers and Prof Corlia van Heerden. I acknowledge as well comments received from delegates to the 2020 Convention of the Actuarial Society of South Africa, to which this paper was presented, and from pre-presentation reviewer, Costa Economou.

\section{Competing interests}

I declare that I have no financial or personal relationships that may have inappropriately influenced me in writing this article.

\section{Author's contributions}

I declare that I am the sole author of this research article.

\section{Ethical considerations}

This article followed all ethical standards for research without direct contact with human or animal subjects.

\section{Funding information}

Financial support for open-source publication is gratefully acknowledged from the University of Pretoria.

\section{Data availability}

Data sharing is not applicable to the article, as no new data were created or analysed in this study.

\section{Disclaimer}

Responsibility for all errors remains mine: the views expressed in this article are my own and are not an official position of the University of Pretoria.

\section{References}

APRA, 2019a, APRA's objectives: Information paper, Australian Prudential Regulation Authority, Sydney, Australia, https://www.apra.gov.au/contact-us

APRA, 2019b, Corporate plan 2019-2023, August, Sydney, Australia, https://www. apra.gov.au/contact-us

APRA, 2019c, Annual report 18/19, September, https://www.apra.gov.au/contact-us

Baldwin, R. \& Black, J., 2016, 'Driving priorities in risk-based regulation: What's the problem?', Journal of Law and Society 43(4), 565-595.

Bar-Gill, O., 2015, 'Price caps in multiprice markets', The Journal of Legal Studies 44(2) 453-476. https://doi.org/10.1086/684300

Bisias, D., Flood, M., Lo, A.W. \& Valavans, S., 2012, 'A survey of systemic risk analytics', Annual Review of Financial Economics 4(1), 255-296. https://doi.org/10.1146/ annurev-financial-110311-101754

Black, J., 2012, Calling regulators to account: Challenges, capacities and prospects, LSE Law, Society and Economy Working Papers 15/2012, London School of Economics and Political Science, London.

Brunnermeier, M., Crocket, A., Goodhart, C., Persaud, A.D. \& Shin, H., 2009, The fundamental principles of financial regulation, Geneva Reports on the World Economy 11, International Center for Monetary and Banking Studies, Geneva, and the Centre for Economic Policy Research, London.

Clark, G.L. \& Monk, A.H.B., 2007a, 'The "crisis" in defined benefit corporate pension liabilities Park II: Current solutions and future prospects', Pensions: An International Journal 12(2), 68-81. https://doi.org/10.1057/palgrave.pm 5950045

Clark, G.L. \& Monk, A.H.B., 2007b, 'The "crisis" in defined benefit corporate pension liabilities Park I: Scope of the problem', Pensions: An International Journal 12(1), 43-54. https://doi.org/10.1057/palgrave.pm.5950041
Committee of Inquiry, 2002, Transforming the present - Protecting the future, Consolidated Report of the Committee of Inquiry into a Comprehensive System of Social Security for South Africa, chaired by Prof Vivienne Taylor, available with supporting reports of the sub-committees, March, https://sarpn.org/ CountryPoverty

Cowling, C.A., Fisher, H.J., Powe, K.J., Sheth, J.P. \& Wright, M.W., 2019, 'Funding defined benefit pension schemes: An integrated risk management approach' British Actuarial Journal 24(7), 1-69. https://doi.org/10.1017/S1357321718 British Act

DSD, 2006, Reform of retirement provisions: Discussion document, Department of Social Development, South African Government, Pretoria.

Erskine, A., 2014, Regulating the Australian Financial System, The Funding Australia's Future Project, Australian Centre for Financial Studies.

Franzen, D., 2010, Managing investment risk in defined benefit pension funds, Working Papers on Insurance and Private Pensions No. 38, OECD Publishing, Paris, https:// www.oecd.org/finance/private-pensions/44899253.pdf

FSB, 2017, 2017 Annual report, Financial Services Board, South Africa, Pretoria, https://www.fsca.co.za/Annual\%20Reports/FSB\%20Annual\%20Report $\% 20$ 2017.pdf

FSB, 2018, Registrar of pension funds annual report 2017, December, Pretoria, https:// www.fsca.co.za/Annual $\% 20$ Reports/Registrar $\% 20$ of $\% 20$ Pension $\% 20$ Funds $\% 20$ Www.fsca.co.za/Annual\%20Rep

FSCA, 2018, Regulatory strategy of the Financial Sector Conduct Authority: October 2018 to September 2021. Financial Sector Conduct Authority, South Africa, undated but published late in 2018, https://www.fsca.co.za/Documents/FSCA Strategy_2018.pdf

FSCA, 2020, Publication of draft Conduct Standard on Communication of benefit projections to members of pension funds, FSCA Communication 31 of 2020 (RF), https://www.fsca.co.za/Regulatory $\% 20$ Frameworks/Temp/FSCA $\% 20$ Communication $\% 2031 \% 20$ of $\% 202020 \% 20$ (RF).pdf

Healy, P.M. \& Palepu, K.G., 2001, 'Information asymmetry, corporate disclosure, and the capital markets: A review of the empirical disclosure literature', Journal of Accounting and Economics 31, 405-440. https://doi.org/10.1016/S01654101(01)00018-0

Holzmann, R., 1999, The World Bank approach to pension reform, Social Protection Discussion Paper Series No. 9807, Social Protection Unit, World Bank, Washington DC, http://www.pensions-institute.org/wp-content/uploads/wp1902.pdf

Holzmann, R., Hinz, R., Von Gersdorff, H., Gill, I., Impavido, G., Musalem, A.R. et al., 2005, Old-age income support in the 21st century: An international perspective on pension systems and reform, World Bank, Washington, DC

ILO, 2017, World social protection report 2017-19: Universal social protection to achieve the sustainable development goals, International Labour Office, Geneva.

IOPS, 2012, IOPS Toolkit for Risk-based Pension Supervision: Case study Kenya International Organisation of Pension Supervisors, Paris, http://www.iopsweb. org/about/contact-us/\#d.en.515236

James, E., 1995, 'Averting the old age crisis: An international perspective', Aging International 22(2), 15-22. https://doi.org/10.1007/BF02681086

Khwaja, A.I. \& Mian, A., 2011, 'Rent seeking and corruption in financial markets', Annual Review of Economics 3, 579-600. https://doi.org/10.1146/annureveconomics-061109-080310

Knot, K., 2014, 'Governance of macroprudential policy', in Financial stability review, 2014, Macroprudential policies: Implementation and interactions, Banque de France, April, Paris, https://ideas.repec.org/a/bfr/fisrev/20141803.html

Laffont, J. \& Martimort, D., 2002, The theory of incentives - The Principala-Agent model, Princeton University Press, Princeton, NJ.

Llewellyn, D.T., 1999, The economic rationale for financial regulation, Occasional Paper Series No. 1, Financial Services Authority, April, Financial Services Authority, London. https://www.fep.up.pt/disciplinas/pgaf924/PGAF/Texto_2_ David_Llewellyn.pdf

Loube, R., 1995, 'Price cap regulation: Problems and solutions', Land Economics 71(3), 286-298. https://doi.org/10.2307/3146347

NPCN, 2018, 2018 Annual report, National Pension Commission of Nigeria, Abuja https://www.pencom.gov.ng/contact-us

NPCSA, 2012, National development plan 2030: Our future - Make it work, Nationa Planning Commission, The Presidency, Government of South Africa, Pretoria, https://www.gov.za/documents/national-development-plan-2030-our-futuremake-it-work

NTSA, 2004, Retirement fund reform: A discussion paper, National Treasury Government of South Africa, December, Pretoria, http://www.treasury.gov.za/ public $\% 20$ comments/Retirement $\% 2$ Fund $\% 20$ Reform $\% 20$ A $\% 2$ Discussion $\% 20$ Paper.pdf

NTSA, 2007, Social security and retirement reform: Second discussion paper, National Treasury, Government of South Africa, February, Pretoria, http://www.treasury. gov.za/documents/national\%20budget $/ 2007 /$ Social\%20security $\% 20$ and $\% 20$ retirement $\% 20$ reform $\% 20$ paper.pdf

NTSA, 2011a, Reviewing the regulation of financial markets in South Africa, National Treasury, Government of South Africa, August, http://www.treasury.gov.za/ public\%20comments/FMB/FMB\%20policy\%20document.pdf

NTSA, 2011b, A safer financial sector to serve South Africa better, Policy document, National Treasury, Government of South Africa, February, https://www.resbank. co.za/en/home/publications/publication-detail-pages/prudential-authority/PAfinancial-sector-regulation/Other-Policy-Considerations/PolicyFramework/2018/8497 
NTSA, 2012, Enabling a better income in retirement, National Treasury, Government of South Africa, Technical Discussion Paper B for Public Comment, September, NTSA 2012, Enabling a better income in retirement, Technical Discussion Paper B for 2012, Enabling a better income
Public Comment, September.

NTSA, 2013, Budget review 2013, National Treasury, Government of South Africa, February, http://www.treasury.gov.za/documents/national\%20budget/2013/review/ FullReview.pdf

NTSA, 2015, Budget review 2015, National Treasury, Government of South Africa, February, http://www.treasury.gov.za/documents/national\%20budget/2015/review/ FullReview.pdf

NTSA, n.d., Explanatory policy paper accompanying The Conduct of Financial Institutions Bill, National Treasury, Government of South Africa, pape accompanying the first draft of the COFI Bill, undated but issued in 2018 along with the Conduct of Financial Institutions Bill (2018), http://www.treasury.gov.za/ twinpeaks/CoFI\%20Bill\%20policy\%20paper.pdf

OECD, 2010, Policy framework for effective and efficient financial regulation: General guidance and high-level checklist, Organisation for Economic Cooperation and Development Publishing, Paris.

OECD, 2019, Pension markets in focus, Organisation for Economic Cooperation and Development Publishing, Paris, https://www.oecd.org/finance/private-pensions/ pensionmarketsinfocus.htm

PASA, 2018, Regulatory Strategy 2018-2021, Prudential Authority, South African Reserve Bank, Pretoria, https://www.resbank.co.za/en/home/publications/ publication-detail-pages/prudential-authority/PA-financial-sector-regulation/ sector-regulation-act/2018/8800

PASA, 2019, Prudential Authority Annual Report 2018/19, Prudential Authority South African Reserve Bank, Pretoria, https://www.resbank.co.za/en/home/ publications/publication-detail-pages/reports/annual-reports/2019/9316

PASA, 2020, Prudential Authority Annual Report 2019/20, Prudential Authority, South African Reserve Bank, Pretoria, https://www.resbank.co.za/en/home/ publications/publication-detail-pages/reports/pa-annual-reports/2020/ 10227

Price, W., Ashcroft, J. \& Hafeman, M., 2016, Outcomes-based diagnosis and assessments for private pensions: A handbook, World Bank, Washington DC, https://openknowledge.worldbank.org/handle/10986/25194
Randle, T. \& Rudolph, H.P., 2014, Pension risk and risk-based supervision in defined contribution pension funds, Policy Research Working Paper 6813, World Bank, Washington, DC. https://openknowledge.worldbank.org/handle/10986/18355

RBA, 2019, Strategic plan 2019-2024, Retirement Benefits Authority, Nairobi, https:// www.rba.go.ke/2019/07/28/launch-of-rba-strategic-plan-2019-2024/

SARB, 2017, Promoting the economic well-being of South Africans: Annual report 2016/17, South African Reserve Bank, Pretoria, https://www.resbank.co.za/en/ home/publications/publication-detail-pages/reports/annual-reports/2017/7858

SARB, 2020, Quarterly Bulletin, South African Reserve Bank, March, https://www. resbank.co.za/en/home/publications/quarterly-bulletin1

Sarkar, A.E., 2009, 'The new mode of public governance and public accountability in developing countries: An analysis with particular reference to Bangladesh' International Journal of Public Administration 32(13), 1101-1123. https://doi. org/10.1080/01900690903188826

SPC, 2019a, Balance de Gestión Integral Año 2018, Management strategy, Superintendency of Chile, Superintendencia de Pensiones, Ministerio del Trabajo y Previsión Social, Chile.

SPC, 2019b, Cuenta Pública, Gestión 2018, Superintendencia de Pensiones, Annual Report of the Superintendency of Chile for Public Participation, Santiago, https:// www.spensiones.cl/portal/institucional/594/w3-propertyvalue-9969.html

Stewart, F. \& Yermo, J., 2008, Pension fund governance: Challenges and potentia solutions, working paper on Insurance and Private Pensions No. 18, OECD, Paris, https://www.oecd.org/finance/private-pensions/41013956.pdf

TPR, 2019a, Corporate Plan: 2019-2022, The Pensions Regulator, Birmingham, https://www.thepensionsregulator.gov.uk/en/document-library/corporateinformation/corporate-plans/corporate-plan-2019-2022

TPR, 2019b, Annual Report and Accounts, 2018-2019, The Pension Regulator Birmingham, https://pmg.org.za/page/AR2018-2019

Willmore, L., 2000, Three pillars of pensions? A proposal to end mandatory contributions, DESA Discussion Paper No. 13, Economic \& Social Affairs, United Nations, New York, https://www.un.org/esa/desa/papers/2000/esa00dp13.pdf

World Bank, 1994, Averting the old age crisis: Policies to protect the old and promote growth, World Bank, Washington, DC. 